\title{
DAS JENSEITS
}

IM

\section{MYTHOS DER HELLENEN.}

\author{
UNTERSUCHUNGEN
}

ÜBER ANTIKEN JENSEITSGLAUBEN

VON

L. RADERMACHER,

\section{BONN}

A. MARCUS UND E. WEBER'S VERLAG.

1903. 



\section{WILHELM KROLL \\ RICHARD WUENSCH}

ZUGEEIGNET. 
